\title{
SEXUAL HARASSMENT IN THE WORKPLACE — TWO STEPS BACKWARD: \\ JANZEN \& GOVEREAU v. PLATY ENTERPRISES LTD.
}

IVAN F. IVANKOVICH*

\section{INTRODUCTION}

Although sexual harassment is a widespread problem in the workplace,' only four jurisdictions within Canada have specifically prohibited it in their human rights legislation. ${ }^{2}$ The remaining jurisdictions, viz., Alberta, ${ }^{3}$ British Columbia, ${ }^{4}$ Manitoba, ${ }^{5}$ New Brunswick, ${ }^{6}$ Nova Scotia, ${ }^{7}$ Prince Edward Island, ${ }^{8}$ Saskatchewan, ${ }^{9}$ and the Yukon and Northwest Territories, ${ }^{10}$ have largely been content to rely on general prohibitions against sex discrimination in employment as, until now, Canadian human rights courts and tribunals have been unanimous in recognizing that sexual harassment may constitute prohibited "sex discrimination" in an increasing number of employment situations. Judicial developments in the United

- Associate Professor of Business Law, Faculty of Business, University of Alberta.

1. See Unwanted Sexual Attention and Sexual Harassment: Results of a Survey of Canadians (Ottawa: Canadian Human Rights Commission, 1983); Sex Discrimination in the Workplace, 1981: Hearings Before the Senate Comm. on Labor \& Human Resources, 97th Cong., 1st Sess. 333-706 passim (Apr. 21, 1981). Generally, see Aggarwal, Sexual Harassment in the Workplace (1987), pp. 1-4. Both men and women can be subjected to sexual harassment: see Romman v. Sea-West Holdings Ltd., (1984), 5 C.H.R.R. D/2312 (Can.). As a matter of linguistic and grammatical convenience, however, this comment will refer in general terms to sexual harassment victims as female.

2. Human Rights Code, 1981, S.O. 1981, c. 53, s. 6(2) and (3); Charter of Human Rights and Freedoms, R.S.Q. 1977, c. C-12, s. 10.1 [en. S.Q. 1982, c. 61, s. 4]; Canadian Human Rights Act, S.C. 1976-77, c. 33, ss. 13.1 \& 13.2 [re-en. 1980-81-82-83, c. 143, s. 7]; Newfoundland Human Rights Code, R.S.N. 1970, c. 262, ss. 10.1 \& 10.2(1) [en. 1983, c. 262, s. 3].

3. Individual's Rights Protection Act, R.S.A. 1980, c. I-2 as am.

4. Human Rights Act, S.B.C., 1984, c. 22.

5. The Human Rights Act, C.C.S.M., c. H175 as am. Following the release of the Janzen decision, discussed infra, the Attorney General for Manitoba indicated the government's intention to amend the Act to specifically prohibit sexual harassment: see the Human Rights Code, C.C.S.M., c. H-175, enacted by S.M. 1987, c. 45, proclaimed in force Dec. 10, 1987.

6. Human Rights Code, R.S.N.B. 1973, c. H-11 as am.

7. Human Rights Act, C.S.N.S., c. H-24 as am.

8. Prince Edward Island Human Rights Act, S.P.E.I. 1975, c. 72 as am.

9. Saskatchewan Human Rights Code, S.S. 1979, c. S-24.1 as am.

10. Fair Practices Ordinance, R.O.Y.T. 1978, c. F-2 as am.; Fair Practices Ordinance, R.O.N.W.T. 1974, C. F-2 as am. 
States," England ${ }^{12}$ and Australia ${ }^{13}$ have inexorably led to the same conclusion.

Against this background, the Manitoba Court of Appeal's recent decision in Janzen and Govereau v. Platy Enterprises Ltd. ${ }^{14}$ represents a dramatic departure from existing authority. Presented with the complaints of two waitresses who were subjected to repeated verbal and physical sexual harassment by a cook with supervisory responsibilities, the court's response sounds a clarion call to those supervisors inclined to use their positions in the workplace to enhance personal sexual gratifications: "If at first you don't succeed, try and try again!"

The decision, in my view, is an unfortunate one. The court's narrow definition of "discrimination because of sex" could eliminate or severely restrict human rights protection against sexual harassment in those jurisdictions that do not have a specific prohibition against it. More pervasively, the decision could have an impact where the harassment relates to other enumerated grounds of discrimination such as age, race, religious belief, mental or physical handicap, etc. ${ }^{15}$ Equally disquieting is the court's extremely restrictive view that an employer is not liable in most cases of employment discrimination unless it has a specific policy to discriminate. The precedential value of this latter aspect may already be problematic in light of the Supreme Court of Canada's recent judgment in Robichaudv. The Queen ${ }^{16}$ rendered subsequent to the Janzen case.

What follows is an attempt to review the Manitoba Court of Appeal's decision in Janzen and critically analyze the two major issues it unsatisfactorily resolved.

\section{THE JANZENCASE}

Dianna Janzen and Tracy Govereau were employed as waitresses at Pharo's Restaurant in Winnipeg. The restaurant was owned by Platy Enterprises Ltd., and managed by Philip Anastasiadis, the president and a director of Platy. Philip was responsible, inter alia, for the hiring,

11. Title VII of the Civil Rights Act, 1964 prohibits sex discrimination in employment but makes no specific mention of sexual harassment. Nevertheless American courts have determined that sexual harassment constitutes prohibited gender-based discrimination: see, e.g., Williams v. Saxbe, 413 F.Supp. 654 (D.C.D.C. 1976); Barnes v. Costle, 561 F.2d 983 (D.C.D.C. 1977); Meritor Savings Bank, FSB, v. Vinson, 106 S.Ct. 2399 (U.S.S.C. 1986).

12. Section 6 of the Sex Discrimination Act, 1975 makes it unlawful for an employer to discriminate against a woman in certain circumstances but, likewise, makes no specific mention of sexual harassment. It has been held that sexual harassment is sex-based discrimination which can be challenged under s. 6 providing, as a result of the harassment, the complainant suffers a detriment related to her employment: see, e.g., Porcelli v. Strathclyde Regional Council, [1985] I.C.R. 177 (E.A.T.).

13. In New South Wales ss. 24(1) and 25(2) of the Anti-Discrimination Act, 1977 prohibit sex discrimination in employment but no specific mention is made of sexual harassment. Here, sexual harassment can amount to discrimination on the ground of sex: see, e.g., $O^{\prime}$ Callaghan v. loder and Commissioner for Main Roads, [1983] 3 N.S.W.L.R. 89 (E.O.T.).

14. [1987] 1 W.W.R. 385, 33 D.L.R. (4th) 32 sub. nom Re Janzen and Platy Enterprises Ltd. (Man. C.A.). Hereafter, the case may be referred to as Janzen.

15. The specific prohibitions against harassment in Ont., Que., Can. and Nfld. extend, insofar as employment is concerned, to all prohibited grounds of discrimination.

16. Robichaud v. The Queen, unreported, 29 July 1987, S.C.C. Hereafter, the case may be referred to as Robichaud. 
instruction, discipline and discharge of employees at the restaurant and also did the cooking during the day shift. Tommy Grammas, the cook during the evening shift, was the person in charge during Philip's absence and had general oversight of the restaurant and its employees. Although Tommy's actual authority did not extend to hiring and firing, Philip held him out to the staff as having such authority.

Ms. Janzen was employed at the restaurant from August until October, 1982. Within a few weeks of her commencing employment, Tommy sexually harassed her by touching areas of her buttocks, abdomen and breasts at unexpected times or at times when she was least able to resist. Ms. Janzen protested and, after about a month, this particular conduct ceased. From that point on, however, Tommy made life difficult for her "... as a cook can do with a waitress who depends on him to provide the orders on a timely basis." " Two weeks before she quit, Ms. Janzen brought the matter to Philip's attention. Her evidence was that he was unsympathetic and told her that she was "overreacting". As a result, she made the decision to resign.

Ms. Govereau's case was similar. She was employed at the restaurant from mid-October to mid-December, 1982. About a week after her employment commenced, Tommy began sexually harassing her with attempted kisses, unwelcomed hugs, pats and suggestive remarks. This situation persisted until mid-November at which time Ms. Govereau complained to Philip. Thereafter the physical harassment ceased but Ms. Govereau complained that Tommy and Philip became overly demanding and unjustly critical of her work. She was ultimately dismissed from her employment by Philip, allegedly on the basis of customer complaints and inadequate work performance.

The Janzen and Govereau complaints were dealt with under the Manitoba Human Rights Act which provides, in part, as follows:

6(1) Every person has the right of equality of opportunity based upon bona fide qualifications in respect of his occupation or employment . . . and without limiting the generality of the foregoing

(a) no employee or person acting on behalf of an employer, shall refuse to employ, or to continue to employ or to train the person for employment or to advance or promote that person, or discriminate against that person in respect of employment or any term or condition of employment ...

because of . . . the sex ... of that person.

Mr. Yude Henteleff, Q.C., the adjudicator appointed under the Act, held that both complainants had been sexually harassed by Tommy, the cook, and that the harassment constituted sexual discrimination contrary to the Act. ${ }^{18} \mathrm{He}$ further held that Platy Enterprises Ltd. was jointly and severally liable with the cook for damages ${ }^{19}$ on what appears to be two grounds: (1) that the corporation was personally liable because the cook was "part of the directing mind of the corporation", and (2) that the corporation was vicariously liable because the sexual harassment was committed by a "person in authority during the course of his employment."

17. Janzen, supra, fn. 14 at p. 390 (W.W.R.), p. 36 (D.L.R.).

18. (1985), 6 C.H.R.R. D/2735 (Man.).

19. For Ms. Janzen the award was $\$ 480$ lost wages plus exemplary damages of $\$ 3500$; for Ms. Govereau the lost wages award was \$3,000: ibid., at pp. D/2771 - D/2772. 
Platy Enterprises Ltd. appealed to the Court of Queen's Bench which upheld the adjudicator's decision but reduced the damages awarded. ${ }^{20}$ Monin J. concluded that Tommy's sexual harassment constituted discrimination on the basis of sex in violation of s. 6(1)(a) of the Act. His Lordship held that the corporate employer was not personally liable to the complainants, but was vicariously liable because Tommy was "in a position of authority over the staff" and the corporation was, consequently, "bound by his actions."

Platy again appealed, and Ms. Janzen and Ms. Govereau cross-appealed to restore the adjudicator's award of damages. Platy based its appeal on three grounds: (1) that sexual harassment was not "discrimination because of sex" under s.6(1)(a) of the Act, (2) that the corporate employer could not be held personally or vicariously liable for the cook's actions, and (3) that the adjudication process under the Manitoba Human Rights Act was ultra vires s. 96 of the Constitution Act, 1867. Huband and Twaddle JJ.A. of the Manitoba Court of Appeal delivered separate and concurring reasons for allowing Platy's appeal on the first two grounds. ${ }^{21}$ Matas J.A. did not participate in the preparation of reasons for judgment. ${ }^{22}$

\section{ANALYZING THE ISSUES}

\section{A. RELATIONSHIP OF SEXUAL HARASSMENT TO SEXUAL DISCRIMINATION}

Huband J.A. is unequivocal in his rejection of any relationship between sexual harassment and sexual discrimination. He begins his judgment with the following words: ${ }^{23}$

I am amazed to think that sexual harassment has been equated with discrimination on the basis of sex. I think that they are entirely different concepts.

In his Lordship's view, these concepts are mutually exclusive ${ }^{24}$ because the prohibitions against discrimination contained in Manitoba's Human Rights Act are solely aimed at discrimination in a "generic sense."' Thus, while an employer would be prohibited from refusing to hire or from

20. [1986] 2 W.W.R. 273, 24 D.L.R. (4th) 31. Exemplary damages for Ms. Janzen were reduced from $\$ 3,500$ to $\$ 1,000 ;$ Ms. Govereau's loss of wages claim was reduced from $\$ 3,000$ to $\$ 500$ and her exemplary damages reduced from $\$ 3,000$ to $\$ 1,500$.

21. Their Lordships disagreed on the third issue. Huband J.A. held that, even if the board of adjudication had the power to award damages for sexual harassment under the Act, the exercise of such power would be ultra vires because it would mean that the tribunal would be making a "judicial determination" and, thus, be operating like a s. 96 court: Janzen, supra, fn. 14 at pp. $414-417$ (W.W.R.), pp. 58-61 (D.L.R.). Twaddle J.A. held that the authority given the board of adjudication under the Manitoba Human Rights Act was intra vires: ibid., at p. 426 (W.W.R.), p. 70 (D.L.R.).

22. Mr. Justice Matas died prior to delivery of the judgment.

23. Janzen, supra, fn. 14 at p. 390 (W.W.R.), p. 35 (D.L.R.).

24. Although Huband J.A., at p. 395 (W.W.R.), p. 41 (D.L.R.), conceded that it was technically possible to posit a hypothetical where the two concepts merge, his bizarre illustration leaves little scope for overlap:

Suppose that an employer wants to hire men only, but in ostensible compliance with the Act he hires women as well as men. Having done so he then decides to make working conditions so miserable for the women that they will resign ... [S]hort of that sort of format, the two concepts do not coincide.

25. Janzen, supra, fn. 14 at p. 398 (W.W.R.), p. 43 (D.L.R.). 
making employment intolerable for "blacks as a group, Jehovah's Witnesses as a group or women as a group", it would be permissible to refuse to hire or to make employment intolerable for specific individuals within the generic classification. ${ }^{26}$ Twaddle J.A., in a similar vein, asserts that, while sexual harassment may, in limited circumstances, amount to discrimination on the basis of sex, this would be so "[o]nly if the woman was chosen on a categorical basis, without regard to individual characteristics . . ."27 Each of their Lordships is, with respect, in error in so narrowly circumscribing the sexual discrimination prohibited by $s$. $6(1)$ of the Manitoba Act.

Mr. Justice Huband, for his part, denies that harassment can ever amount to discrimination. He employs the inapposite example of a situation in which a schoolboy kisses a female classmate. He opines that while this is harassment, perhaps, "... [the schoolboy] surely is not discriminating against her."28 The logic of this reasoning is far from compelling. Where his kisses are unwelcome, the schoolboy, by his conduct, is surely "differentiating" or "making a distinction", to use the very definitions of discrimination advanced by Huband J.A., ${ }^{29}$ between that schoolgirl and other schoolmates, male and female, who are not the immediate objects of his attention. Viewed from her perspective and, it might be suggested, from the perspective of the reasonable bystander, the schoolboy's conduct can readily be characterized as "discriminating against her", albeit not in violation of any human rights legislation. For Mr. Justice Huband, however, the Janzen and Govereau complaints are essentially dismissed at this stage.

Huband J.A.s judgment is all the more surprising for its summary rejection of the Cherie Bell ${ }^{30}$ line of cases on the ground that these cases improperly "equate" sexual harassment with prohibited discrimination on the basis of sex. With respect, these cases do nothing of the sort. What they universally affirm is that sexual harassment may, in certain cases, violate the general prohibition in human rights legislation against sex discrimination in employment. ${ }^{31}$ Mr. Shime, constituting the Board in Cherie Bell, imposed a strict requirement that a complainant show that compliance with a superior's sexual advances was a "term or condition of employment." It is noteworthy that the complainant, Ms. Cherie Bell, was herself unsuccessful, notwithstanding that she was sexually harassed, precisely

26. Id.

27. Ibid., at p. 422 (W.W.R.), p. 66 (D.L.R.).

28. Ibid., at p. 395 (W.W.R.), p. 41 (D.L.R.).

29. Id.

30. Bell v. Ladas (1980), 1 C.H.R.R. D/155, 27 L.A.C. (2d) 227 sub nom. Re Bell and Korczak. Hereafter, the case may be referred to as Cherie Bell.

31. Admittedly, some statements have been made by boards and tribunals which, if taken out of context, appear to unequivocally assert the equation of sexual harassment with prohibited sexual discrimination. It is suggested, however, that upon complete examination these decisions also support a permissive rather than mandatory equation. The case of Hughes v. Dollar Snack Bar, (1981), 3 C.H.R.R. D/1014 (Ont.), is illustrative. Although Professor Kerr states, at p. D/1015, that "... [sexual] harassment itself is a discriminatory condition of employment based on sex"' he clearly recognized, at p. D/1016, that something more than harassment per se was necessary to link Ms. White's harassment to a term or condition of her employment. 
because she was unable to establish the prerequisite nexus between the impugned conduct and the effect on her employment. ${ }^{32}$ While it is true that the Board went on to suggest a broad interpretation of the phrase "term or condition of employment" to include sexual harassment "which may reasonably be perceived to create a negative psychological and emotional work environment,"33 this was not an "equation" of sexual harassment with prohibited sexual discrimination. ${ }^{34}$ Rather, it was an express recognition that the employment consequences flowing from the sexual harassment may be tangible - a "quid pro quo", ${ }^{35}$ or intangible - a "hostile and offensive work environment:" ${ }^{36}$ In either case, however, a cause and effect relationship must be established.

As noted by Aggarwal, there is often an overlap between consequences ${ }^{37}$ and the instant case is illustrative. The cook's unwelcomed and continued touching of Ms. Janzen's buttocks, abdomen and breasts over a period of one month, for example, might well have constituted an "offensive and hostile work environment" sufficient to invoke the statutory protection. Although he thereafter stopped the touching per se, Tommy retaliated for Ms. Janzen's rebuff by failing to provide her orders on a timely basis. This was a tangible job-related consequence for a waitress, as was her constructive dismissal..$^{38}$

In the result, then, Ms. Janzen, it is submitted, successfully met the onus of establishing that compliance with Tommy's sexual advances was, in effect, a "term or condition of her employment" at Pharo's Restaurant. It should only have remained to consider whether that term or condition

32. Cherie Bell, supra, fn. 30 at p. D/159. See also, e.g., Aragona v. Elegant Lamp Co. Ltd. (1982), 3 C.H.R.R. D/1109 (Ont.); Fullerton v. Davey C's Tavern unreported, 1983, Ont. H.R. Comm.

33. Cherie Bell, ibid., at p. D/156.

34. As Professor Ratushny stated in Aragona v. Elegant Lamp Co. Ltd., supra, fn. 32 at p. D/ 1110.

... (S)exual references which are crude or in bad taste, are not necessarily sufficient to constitute a contravention of section 4 of the Code on the basis of sex. The line of sexual harassment is crossed only where the conduct may be reasonably construed to create, as a condition of employment, a work environment which demands an unwarranted intrusion upon the employee's sexual dignity as a man or woman. The line will seldom be easy to draw ..."

35. Catherine Mackinnon in Sexual Harassment of Working Women: A Case of Sex Discrimination (1979), p. 32, sets out two polar categories of sexual harassment. The first category referred to as "quid pro quo" occurs, for example, where an employer demands sexual favours from an employee, the employee refuses, and the employer retaliates with a jobrelated reprisal.

36. The second category of sexual harassment, styled "conditions of work", does not involve any atempt to force the employee into sexual conduct but, rather, involves creating, through such things as gender-based insults, threats, jokes etc., a work environment which is more hostile and offensive for one gender than the other: see Mackinnon, ibid., at p. 40. For a general discussion, see Backhouse, "Bell v. The Flaming Steer Steak House Tavern: Canada's First Sexual Harassment Decision" (1981), 19 U.W.Ont.L. Rev. 141 at pp. 143145.

37. Aggarwal, op. cit. supra, fn. 1 at p. 86 where the author notes, "If unwanted sexual overtones lead to adverse job-related consequences for an employee that does not mean the employee's job environment had not become offensive". See, e.g., McPherson v. Mary's Donuts (1982), 3 C.H.R.R. D/961 (Ont.).

38. See, e.g., Coutroubis v. Sklavos Printing, (1981), 2 C.H.R.R. D/457 (Ont.). The facts in Ms. Govereau's case, as established by the adjudicator, lend themselves to a similar analysis. 
discriminated against her because of "sex"39 and, if so, whether it was imposed on her employment by an "employer or person acting on behalf of an employer:"

Mr. Justice Twaddle, for his part, initially concedes that sexual harassment may constitute prohibited discrimination, but thereafter restricts discrimination "because of sex" to discrimination directed exclusively against men or women as a group: ${ }^{40}$

The gender of a woman is unquestionably a factor in most cases of sexual harassment. If she were not a woman the harassment would not have occurred. That, however, is not decisive ... Only a woman can become pregnant, but that does not mean that she becomes pregnant because she is a woman. We are concerned with the effective cause of the harassment ...

Focusing on a singular effective cause of discrimination clearly precludes a successful complaint against an employer who refuses to hire any woman with black hair. More perturbing, it arguably precludes initiating a successful complaint against an employer who refuses to hire any woman who is handicapped.4 In order for the employer's conduct to constitute discrimination against a female complainant because of sex, in Twaddle J.A.s view, the impugned conduct must be directed toward all women equally. He cites the fact that a third waitress at the restaurant was not sexually harassed by Tommy as sufficient to establish that Ms. Janzen and Ms. Govereau were harassed because of ". . . characteristics peculiar to them rather than because of their sex." 42

This patent refusal to acknowledge the possibility of more than one operative cause for harassment or discrimination is, with respect, unsupportable. The gender of the victim will usually be an important contributing variable to sexual harassment. This causal link is apparent if one considers that it is only because a women is a woman that sexual compliance is requested. Thus, gender will usually be the sine qua non in both the heterosexual and homosexual contexts of harassment, ${ }^{43}$ although rarely, if ever, its singular effective cause.

In addressing this type of problem, Canadian precedents have clearly established that a prohibited consideration need not be the "sole","

39. Huband J.A.s approach is that "discrimination" only deals with generic classifications and, thus, the conduct is not directed toward Ms. Janzen "because of sex" in any event. Twaddle J.A., on the other hand, rests his decision precisely on this issue as discussed infra: see text accompanying fns. 40-53.

40. Janzen, supra, fn. 14 at p. 423 (W.W.R.), p. 67 (D.L.R.).

41. Although an employer is prohibited from categorically refusing to hire women or physically handicapped persons, this anomalous result arguably follows because the discrimination as illustrated is not directed against women as a group nor physically handicapped persons as a group.

42. Janzen, supra, fn. 14 at p. 425 (W.W.R.), p. 70 (D.L.R.).

43. These situations can be distinguished from the example of a bisexual supervisor who conditions the employment opportunities of either gender upon participation in sexual activities. This, admittedly, would not constitute gender discrimination because it applies to male and female employees alike. The bisexual employer, however, seems to be a rare and elusive creature.

44. See, e.g., MacBean v. Village of Plaster Rock, unreported, 1975 N.B.H.R. Comm. at pp. 56. 
"effective", 45 or "major" cause for discriminatory conduct to be held in violation of human rights legislation; it suffices if the prohibited consideration "is present in the mind", 4 is "in fact considered", ${ }^{48}$ is a "significant reason", Simcoe County Board of Education "s1, after an exhaustive review of human rights decisions on the issue of "mixed motives", Chairman Cumming concludes:

To sum up, if one of the main reasons for dismissing the employee, or refusing to hire a person, is a reason prohibited by the Human Rights Code, the Code has been violated regardless of any other reasons for that act.

The American jurisprudence is equally emphatic in maintaining that discrimination is sex discrimination whenever sex is a substantial factor in the discrimination. ${ }^{52}$

In light of such well-established authorities, it is somewhat puzzling that Mr. Justice Twaddle neglects or refuses to articulate any reasons to support his unorthodox view. If the purpose of human rights legislation is, inter alia, to eliminate prohibited factors from consideration in decisions affecting employment, that purpose is essentially negated if prohibited factors can validly be considered in conjunction with other factors. Practical considerations, as well, belie the adoption of this approach..$^{53}$

\section{B. SCOPE OF EMPLOYER LIABILITY}

Given their concurrent rulings that Tommy the cook's sexual harassment of Ms. Janzen and Ms. Govereau was not prohibited sexual discrimination under the Manitoba Human Rights Act, it was unnecessary for Huband and Twaddle JJ.A. to deal with the question of employer responsibility for discriminatory conduct in the workplace. Nevertheless, their Lordships went on to suggest extremely narrow parameters.

45. See, e.g., Brewer v. Board of School Trustees, School District No. 62 (Sooke) unreported, 1977 B.C.H.R.Comm. at p. 13.

46. See, e.g., Fuller v. Candur Plastics Ltd., (1981) 2 C.H.R.R. D/419, D/422 (Ont.).

47. Hawkes v. Brown's Ornamental Iron Works unreported, 1977 Ont. H.R. Comm. at p. 16.

48. Holloway v. MacDonald and Clairco Foods Ltd., (1983), 4 C.H.R.R. D/1454, D/1457 (B.C.).

49. Bremer v. Board of School Trustees, supra, fn. at p. 14.

50. Fuller v. Candur Plastics Ltd., supra, fn. 46 at p. D/422.

51. (1983), 4 C.H.R.R. D/1203, D/1207 (Ont.).

52. See Bundy v. Jackson, 641 F2d 934 at 942 (D.C.Cir. 1981). See, also, Barnes v. Costle, supra, fn. 11 at p. 990, where the United States Court of Appeals for the District of Columbia stated:

It is clear that the statutory embargo on sex discrimination in employment is not confined to differentials founded wholly upon an employee's gender. On the contrary, it is enough that gender is a factor contributing to the discrimination in a substantial way.

53. As stated by Professor Kerr in MacBean v. Village of Plaster Rock, supra, fn 44 at pp. 5-6: ... In order to determine whether a prohibited reason was the sole or primary reason for a decision, it would be necessary for the Board to assume the place of the employer making the decision and analyze in full the process, mental and otherwise, which led to his decision. Such an extensive interference with the appropriate internal management functions of an employer cannot have been intended by the legislature, particularly when the declared purpose of the Act can be better accomplished by the much less involved method of determining merely whether a prohibited reason formed a part of the reasons for the decision. 
In the courts and tribunals below, Platy Enterprises Ltd., the corporate employer, was held personally ${ }^{\text {s4 }}$ and/or vicariouslyss liable for Tommy's conduct. Huband J.A. provides extensive reasons for negativing Platy's liability on both counts. With respect to vicarious liability, he asserts that the Act does not provide for it and, in the absence of a clear statutory provision, vicarious liability should not be implied. He draws support from the wording of s. 28(2)(c) of the Manitoba Act which provides for the imposition of a penalty or exemplary damages against a "person who contravened the Act", noting that "[i]t makes little sense to impose [such] liability ... against one who has been guilty of no fault and is deserving of no punishment:" ${ }^{6}$ His Lordship then reaffirms the principle, set out by the Manitoba Court of Appeal in Dakota Ojibway Tribal Council v. Bewza, that an employer will not incur liability under the Manitoba Act unless it has a policy to discriminate or is an accomplice to the act of discrimina-

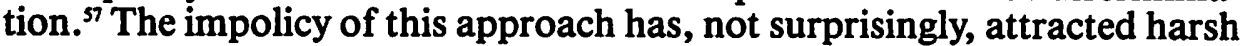
criticism. Kathleen Ruff questions the likelihood of employers couching discriminatory practices in so convenient a format: ${ }^{58}$

Even if you could prove that you were denied a job because of your race, or because of your disability or because of your age, or your sex, the employer would not be responsible, nor would the person who committed the act, unless you could prove that the act of discrimination was the employer's policy. You would need, for example, to produce evidence that the employer had a policy in writing or in words, Do Not Hire Members of Racial Minorities; Do Not Hire Persons With A Disability, Sexually Harass Women, etc.

After concluding that an employer's potential for liability under the Manitoba Act is restricted to personal rather than vicarious liability, ${ }^{59} \mathrm{Mr}$. Justice Huband curiously combines the tests for imposing liability under these different concepts. In addressing the issue of personal liability, he initially finds that Tommy, the cook, was not the directing mind and will of the corporate employer. ${ }^{60}$ With respect, that should have been sufficient to dispose of the question. If the impugned conduct is committed by the "directing mind" in the course of the employer's business, that suffices to impose liability under the organic theory of corporate responsibility. ${ }^{61}$ It

54. Corporate employers have been held "personally" liable on an organic theory of corporate responsibility. According to this theory, because a corporation can only act through those who direct its affairs, the acts of employees who are part of the "directing mind and will of the corporation" are those of the corporation itself. Professor Cumming has discussed the application of this theory to discrimination cases: see, e.g., Olarte v. Commodore Business Machines, (1983), 4 C.H.R.R. D/1705 at pp. D/1740 - D/1741 (Ont.). For a complete discussion, see Aggarwal, op. cit. supra, fn. 1 at pp. 120-123.

55. Vicarious liability is a common law concept that imposes responsibility on an employer for its employee's wrongful conduct where the employee acted (1) within his actual or ostensible authority and (2) in the course of his employment. The concept has been extended to discrimination cases in Canada: see, e.g., Oram and McLaren v. Pho, unreported, 1975 B.C.H.R.Comm. For a complete discussion, see Aggarwal, ibid., at pp. 117-120.

56. Janzen, supra, fn. 14 at p. 407 (W.W.R.), p. 52 (D.L.R.).

57. [1986] 2 W.W.R. 225, at p. 235; 24 D.L.R. (4th) 374, 383 cited by Huband J.A. at p. 408 (W.W.R.), P. 53 (D.L.R.).

58. (1987), 3 Can. Hum. Rts. Adv. 1 at p. 2. Semble, Meritor Savings Bank, FSB v. Vinson, 106 S.Ct. 2399, 2410 (U.S.S.C. 1986), per Marshall J.

59. Twaddle J.A., even more restrictively, asserts that no liability should be imposed on the corporate employer even if it condoned the cook's conduct; only if Platy "adopted" that conduct should it be liable: see Janzen, supra, fn. 14 at p. 426 (W.W.R.), p. 70 (D.L.R.).

60. Ibid., at pp. $410-411$ (W.W.R.), p. 55 (D.L.R.).

61. See fns. 54 and 55. 
unnecessarily confuses the issue to additionally require, as does Huband J.A., that the impugned conduct be committed by the directing mind in the course of his employment. This inquiry into Tommy's actual and ostensible authority led his Lordship to query: ". . . [W] [Wat has patting the buttocks of a waitress to do with fulfilling the responsibilities of a cook?"'2 Assuming Tommy was the "directing mind", the proper question should have been that suggested by Professor Cumming in a recent post-Janzen decision, viz., "... [W] as the cook acting in the course of carrying on the corporation's business, when he would pat the buttocks of the waitress?"63

In any event, the Supreme Court of Canada appears to have just recently sounded the death knell for vicarious and organic notions of employer liability. In Robichaud v. The Queen ${ }^{64}$ the Court unanimously ruled that the Department of National Defence was liable for the conduct of Dennis Brennan, a supervisor, who sexually harassed Ms. Robichaud while she was a probationary employee on a cleaning crew at the Canadian Forces base in North Bay, Ontario. In the proceedings below, relied upon by Huband and Twaddle JJ.A. in the Janzen case, ${ }^{65}$ the Federal Court of Appeal refused to find the Department of National Defence liable unless someone at the "director level" had authorized or condoned her supervisor's conduct. ${ }^{66} \mathrm{Mr}$. Justice LaForest, writing for the Supreme Court, ${ }^{67}$ unequivocally disputed this interpretation, stating that it was "completely beside the point" when dealing with human rights legislation to refer to theories of employer liability developed in the context of criminal or quasicriminal conduct ${ }^{68}$ Similarly, he eschewed the application of the doctrine of vicarious liability in tort to the statutory scheme. ${ }^{69}$ Instead, LaForest $\mathrm{J}$. re-emphasized the Supreme Court of Canada's recent decisions prescribing a purposive, effects-oriented approach to the interpretation of human rights legislation, ${ }^{70}$ leading him ineluctably to conclude that the purpose was ". . . remedial - to eradicate anti-social conditions without regard to

62. Janzen, supra, fn. 14 at p. 411 (W.W.R.), p. 55 (D.L.R.).

63. Boehm v. National System of Baking, Ltd., unreported, 1987 Ont. H.R. Comm. at p. 41.

64. Supra, fn. 16.

65. Supra, fn. 14 at pp. 406-407 (Huband J.A.), p. 424 (Twaddle J.A.) [W.W.R.]; pp. 51-52, p. 68 [D.L.R.].

66. Brennan v. R. [1984] 2 F.C. 799, (1985) 6 C.H.R.R. D/2695 sub. nom Treasury Board v. Robichaud, 57 N.R. 116 sub. nom Brennan v. Can. In Ms. Robichaud's case, this would have meant the Minister of National Defence or the President of the Treasury Board.

67. The judgment of Dickson P.C. and La Forest, McIntyre, Lamer, Wilson and L'HeureuxDube J.J. was delivered by La Forest J. Le Dain J. delivered a concurring one paragraph judgment in which, inter alia, he agreed that the appeal should be allowed for the reasons given by La Forest $\mathrm{J}$.

68. Robichaud, supra, fn. 16 at pp. 6-7.

69. Ibid., at p. 7.

70. See Ontario Human Rights Commission and O'Malley v. Simpsons-Sears Ltd., [1985] 2 S.C.R. 536, 7 C.H.R.R. D/3102, 23 D.L.R. (4th) 321 sub. nom Re Ontario Human Rights Com'n and Simpsons-Sears Ltd. (S.C.C.); Bhinder v. Canadian National Railway Company, [1985] 2 S.C.R. 561, 7 C.H.R.R. D/3093, 23 D.L.R. (4th) 481 sub. nom Re Bhinder and Canadian National Ry. Co. (S.C.C.). For a complete discussion, see Ivankovich, "The 'Religious' Employee and Reasonable Accommodation Requirements" (1987), 13 C.B.L.J. 313. The same approach was emphasized by Dickson C.J.C. just one month prior to the S.C.C. decision in Robichaud: see Action Travail des Femmes v. Canadian National Railway Co., June 25, 1987 (as yet unreported). 
the motives or intention of those who cause them." This purpose, he averred, is inherent in the substantive provision in s. 2 of the Canadian Human Rights Act which expressly seeks "to give effect" to the principle of equal opportunity without discrimination. According to a prior decision of the Supreme Court, such a purpose is also inherent in provincial legislation which contains a preamble declaring public policy ".... to provide for equal rights and opportunities without discrimination." $A$ fortiori, the opening words of s. 6(1) of the Manitoba Act, which provide that "Every person has the right of equality of opportunity based upon bona fide qualifications in respect of . . . employment," similar effect.

Mr. Justice LaForest, in applying the purposive approach to the Canadian Human Rights Act, opined that its remedial objectives would be "stultified" if the remedies provided were not also available against the employer: ${ }^{74}$

Indeed, if the Act is concerned with the effects of discrimination rather than its causes (or motivations), it must be admitted that only an employer can remedy undesirable effects; only an employer can provide the most important remedy - a healthy work environment. The legislative emphasis on prevention and elimination of undesirable conditions, rather than on fault, moral responsibility and punishment, argues for making the Act's carefully crafted remedies effective ... .

Hence, I would conclude that the statute contemplates the imposition of liability on employers for all acts of their employees "in the course of employment", interpreted in the purposive fashion outlined earlier as being in some way related or associated with the employment. It is unnecessary to attach any label to this type of liability; it is purely statutory.

Although the remedies available to the victims of employment discrimination enumerated in s. 41(2) of the federal Act are very broad, ${ }^{75}$ it is important to note that a tribunal is limited to ". . . mak[ing] an order against the person found to ... have engaged in the discriminatory practice." The wording is, therefore, very similar to that which was considered in the Janzen case ${ }^{76}$ where, under s. 28(2) of the Manitoba Act, authority is given to make an order against "the party" or "the person who has contravened the Act:" In addition, LaForest J. relied upon the educational objectives embodied in the federal legislation, ${ }^{n}$ which are

71. Robichaud, supra, fn. 16 at p. 7.

72. See Ontario Human Rights Commission and O'Malley v. Simpsons-Sears Ltd., supra, fn. 70.

73. It should also be noted that the specific prohibitions under clauses (a), (b) and (c) of s. 6(1) are delineated "without limiting the generality of the foregoing": see Hufnagel v. Osama Enterprises Ltd., (1982), 3 C.H.R.R. D/922 at p. D/925 (Man.).

74. Robichaud, supra, fn. 16 at pp. 10-11.

75. These remedies include the power to order, inter alia, the adopting of a special program to prevent similar discrimination in the future and the restoration of such rights, opportunities or privileges that were denied to the victim as a result of the discrimination. By contrast, the remedies available under the Manitoba Act are restricted to wages, lost salary or expenses incurred as a result of the discrimination: see s. 28(2)(a). Both Acts provide for exemplary damages under special circumstances: s. 41(3) [Can.], s. 28(2)(b) [Man.].

76. Indeeed, this was expressly acknowledged by Huband J.A.: Janzen, supra, fn. 14 at p. 408 (W.W.R.), p. 53 (D.L.R.).

77. See Canadian Human Rights Act, supra, fn. 2, s. 22(1)(a). 
similar to those contained in the Manitoba $A c t,{ }^{78}$ to support his broad interpretation of employer liability. ${ }^{79}$

It must be emphasized that in the Robichaud case the parties did not question the finding below that the supervisor's conduct contravened the Canadian Human Rights Act. This obviated the need for the Supreme Court to address the issue of whether the sexual harassment of Ms. Robichaud constituted prohibited sexual discrimination. The sole question before the Court was whether or not, in the circumstances, the employer was liable for the prohibited conduct. If, for the purposes of the Janzen case, Tommy's sexual harassment of the complainants did constitute "discrimination because of sex" under the Manitoba Act, the Robichaud precedent appears to be dispositive of the issue of Platy Enterprises Ltd's liability for that sexual harassment.

\section{CONCLUSION}

In Janzen v. Platy Enterprises Ltd. the Manitoba Court of Appeal clearly demonstrated its hostility to the purpose and role of human rights legislation and erected an insurmountable barrier to achieving the "equality of [employment] opportunity" guaranteed in s. 6(1) of the Manitoba Human Rights Act. The emergent, narrow definition of "discrimination because of sex" is unwarranted by precedent or policy. The court, with respect, misinterpreted the relationship between sexual harassment in the workplace and sexual discrimination in employment as prohibited by $\mathrm{s}$. 6(1). The immediate impact of this aspect of the Janzen ruling is to foster uncertainty in those jurisdictions where human rights legislation does not provide specifically for a prohibition against harassment in employment on any of the prohibited grounds. The ultimate impact will not be apparent until the Supreme Court of Canada deals with this issue.

In the wake of Robichaud, the question of a corporate employer's liability for prohibited discrimination does not depend upon such considerations as whether it condoned, adopted or had a policy permitting such conduct, whether the perpetrator was the "directing mind" of the corporation or whether the discrimination occurred in the "course of employment". The Supreme Court's imposition of broader employer liability without regard to labels is theoretically welcome and recognizes the employer's superior position to know what is happening in the workplace, to take preventive measures to lessen the incidence of discrimination and to instil sensitivity and a willingness to deal with discrimination in managerial and supervisory personnel.

78. Section 13(c).

79. Mr. Justice LaForest avers that the educational function would be "vitiated" if a narrower scheme of employer liability were fashioned. His broad approach, by contrast, "... makes education begin in the workplace ... rather than in society at large": Robichaud, supra, fn. 16 at p. 10. 
Mr. Justice LaForest's judgment in Robichaud is the most articulate explication and the furthest extension of the Supreme Court of Canada's willingness to prescribe that human rights legislation be interpreted to protect the quality of the work environment. It remains for the Supreme Court to conclusively determine whether freedom from sexual harassment is impliedly a part of that "healthy work environment." 80 granted June 25, 1987 (Dickson C.J.C., Estey and La Forest J.J.). 